\title{
THE STATUS OF THE GENERIC NAMES MICROCOCCUS AND ST APHYLOCOCCUS AND OF THE SPECIES NAME STAPHYLOCOCCUS AUREUS
}

Request for an Opinion. File No. 23.

T. Gibson

School of Agriculture, Edinburgh.

Since the end of last century the Gram-positive catalaseforming cocci that do not form cell groups of regular form have usually been allotted either to $\mathrm{Micrococcus}$ Cohn or to $\mathrm{Staphylococcus}$ Rosenbach. In 1885 Zopf $(9, \mathrm{p} .51)$ regarded these genera as inseparable, and later investigators have consistently failed to find a criterion by which the organisms could be divided into two groups each deserving generic status. Despite the virtual unanimity that has been reached in taxonomy both generic names continue to be used for the same species. This unfortunate situation appears to derive in part from custom and in part from the difficulties in applying the Bacteriological Code of Nomenclature to cases in which the identity of the original nomenclatural type is uncertain. In view of the urgency of the question the Judicial Commission is requested to issue an Opinion on the status of $\mathrm{Micrococcus}$ and Staphylococcus. In the following statement an attempt is made to indicate the more relevant aspects of the case.

\section{Micrococcus}

This name was proposed in 1872 by Cohn $(3$, p. 15) for bacteria with spherical or oval, non-motile cells which occur in pairs, short chains or clumps. No type species was designated, and itis therefore pertinent to consider the species that were included. Prominence was given by $\mathrm{Cohn}$ to the pigment-forming organisms that he and his collaborator Schroeter (6) obtained on slices of cooked potato and other media kept in a moist atmosphere under bell jars. The first six species in Cohn's list were secured in that way. The sequence in which they are given is: Micrococcus prodigiosus, M. luteus, M. auratiacus, M. chlorinus, $M \cdot$ cyaneus and $\bar{M} \cdot \overline{\text { violaceus. Both authors }}$ 
devote much more attention to $M$. prodigiosus than to the other species. Among the few diagnostic characters mentioned are the colours and the solubilities of the pigments formed. This information indicates that several of the organisms would now be regarded as rod forms, probably as motile rods. Cohn states that all have the same morphology.

Fourteen years later Schroeter (7) produced a classification of twenty-eight species of $\mathrm{Micrococcus}$ in which the pre-

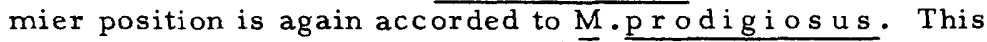
contribution and also Zopf's book (9), published a year earli$\mathrm{er}$, although they include rod forms in $\mathrm{Micrococcus}$, do also incorporate an indisputably genuine coccus which can be recognized today, the $\mathrm{Micrococcus}$ aureus (Rosenbach) Zopf.

It is evident that Cohn's Micrococcus comprises a group quite different from that to which the name is now applied. With the later restriction of the genus to coccal bacteria problems have arisen concerning its type species. Buchanan (2, p. 613) proposed $\mathrm{Micrococcus}$ luteus as the type. The draft revision of Rule 9 of the Code of Nomenclature (see this BULLETIN 1, (3), 129-130) when applied to this case requires that Buchanan's choice of type species must be accepted unless it can be proved that his choice is not in accordance with the rules. Conformity to the rules necessitates that $\underline{M}$. luteus is identifiable; that is a question needing clarification.

Cohn was unable to secure and maintain pure cultures - a fact which he himself recognized and deplored (3,p. 129) and his description of $\mathrm{M}$. lute us includes only two definite characters: (1) the production of an insoluble yellow pigment and (2) the ability to produce a thick, folded, yellow pellicle and a yellow deposit in a solution containing ammonium tartrate as the only source of carbon and nitrogen. Schroeter (7), after gelatin had been introduced into bacteriological work, recorded the type of colony and the absence of liquefaction on that medium. It may be noteworthy that Schroeter in both of his publications $(6, \mathrm{p} .119 ; 7, \mathrm{p} .144)$ states that the organism is elliptical in shape. The possibility cannot 
therefore be excluded that $M$. lute us Cohn was but another of the rod forms that were originally allotted to $\mathrm{Micro-}$ coccus. Later workers have questioned the adequacy of the descriptions of M. 1 u te us provided by Cohn and Schroeter. In 1896 Lehmann and Neumann (4), who have frequently been credited with the first useful treatment of the genus Micrococcus, decided (p. 161) that M.luteus Cohn could not be identified. They proceeded to define the species afresh.

Breed (1) rejects $M$. 1uteus Lehmann and Neumann on the grounds that it differs from the $M$. luteus described in Schroeter's second paper (7) in liquefying gelatin. In an addendum to his paper Breed proposes that a culture (ATCC no. 398 ) identified as $\underline{M}$. 1 uteus by Hucker should be selected as the type culture for the type species of the genus Micrococcus. Apparently under the rules this proposal must also be rejected because ATCC no. 398 does not posess one of the few known characters of $M$. luteus Cohn, the ability to grow in a tartrate $-\mathrm{NH}_{3}-$ salts solution.

It may not be easy to find a micrococcus that conforms to Cohn's original description in producing a yellow growth and also in developing profusely in an ammonium tartrate solution. Attempts have been made in the writer's laboratory to isolate one from air and other sources; bacteria which form yellow colonies on tartrate $-\mathrm{NH}_{3}$ agar have often been obtained, but so far in every instance they have been rods, most frequently short diphtheroid (coryneform) rods.

In summary, it would appear that prior to the year 1885 Micrococcus was not a legitimate generic name for organisms now recognized as cocci. Not until that date, in the publication of $Z$ opf (9), was a definite coccus placed in the genus. Zopf transferred that species from Staphylococcus.

\section{Staphylococcus}

As a generic name $S$ taphylococcus was introduced in 1884 by Rosenbach (5) when he described $S$. aureus and S. albus. Buchanan $(2$, p. 612) designated $\overline{S t a p h y l o c o c}-$ 
cus aureus as the type species. In Rosenbach's publication that species was on page 19 named $S t a p h y l o c o c c u s$ pyogenes aureus, but later (p. 27) the acceptable binomial Staphylococcus aureus was introduced. The validity of the latter name can scarecely be questioned. Noteworthy is that no subsequent author appears to have doubted the identity of the original cultures of $\underline{S}$. a u r e us, and also that this name was proposed at a date when the genus $\mathrm{Micrococcus}$ was still in essentially the same state as that in which it had been left in 1872 by Cohn.

Shaw, Stitt and Cowan (8) have proposed as the type culture of Staphylococcus aureus the widely known strain FDA 209-P (ATCC 7538 P, NCTC 7447).

\section{DRAFT PROPOSALS}

The Judicial Commission is asked to prepare and issue an Opinion on the status of the generic names Micrococcus and $\mathrm{Staphylococcus.}$. The following draft proposals are suggested:

1. Staphylococcus Rosenbach is (is not) recognized as a nomen genericum conservandum.

2. Staphylococcus aureus Rosenbach is (is not) recognized as the type species of the genus $\mathrm{Staphylococ-}$ cus Rosenbach.

3. The culture FDA $209-P$ is (is not) recognized as the type culture of the species Staphylococcus aureus Rosenbach.

4. In the year $1884 \mathrm{Micrococcus}$ was an illegitimate (a legitimate) generic name in bacteriology.

\section{REFERENCES}

(1) Breed, R.S. The type species of the genus Micrococcus. Int. Bull. Bact. Nomen. and Taxon. 2:85-88. 1952.

(2) Buchanan, R.E. Studies in the nomenclature and classification of the bacteria. IV. Subgroups and genera of 
BACTERIOLOGICAL NOMENCLATURE AND TAXONOMY

the Coccaceae. J. Bact. 2:603-617. 1917.

(3) Cohn, F. Untersuchungen über Bacterien. Beitr. Biol. Pflanz. 1:127-224. 1872 .

(4) Lehmann, K. B. and Neumann, R. Atlas und Grundriss der Bakteriologie. München: J.F. Lehmann, 1896.

(5) Rosenbach, F.J. Mikroorganismen bei den Wundinfectionskrankheiten des Menschen. Wiesbaden: J. F.Bergmann. 1884 .

(6) Schroeter, J. Ueber einige durch Bacterien gebildete Pigmente. Beitr. Biol. Pflanz. 1:109-126. 1872.

(7) Schroeter, J. In Cohn, F. Kryptogamen-Flora von Schlesien. 3:143-149. Breslau: J.U.Kern's Verlag. 1886.

(8) Shaw, C., Stitt, J. M. and Cowan, S. T. Staphylococci and their classification. J. Gen. Microbiol. 5:10101023. 1951 .

(9) Z opf, W. Die Spaltpilze. 3.Aufl.pp.51-57. Breslau: E. Trewendt. 1885 . 